\title{
A rationale for integrating writing into secondary content area classrooms: Perspectives from teachers who experience the benefits of integrating writing frequently
}

\author{
Hannah Carter $^{1} \&$ Dianna R. Townsend ${ }^{2}$ \\ ${ }^{1}$ Boise State University | USA; ${ }^{2}$ University of Nevada | USA
}

\begin{abstract}
Teachers navigate ongoing accountability pressures that target writing in each content area, yet little is understood about their experiences with or their rationales for integrating writing into content area lessons. While previous research describes writing in U.S. secondary classrooms and explains barriers to writing integration, this study investigates teacher decision making to determine why teachers in various content areas are integrating writing. Using a multicase study design, we explored teacher reflections to discern the reasons why teachers chose to integrate writing frequently. Four teachers, one from each primary content area (mathematics, English language arts, science, social studies), reflected on their writing integration over one quarter. Findings revealed that teachers who integrate writing frequently value the substantial benefits of regular writing for their students. Teachers saw that frequent writing led to students both producing written products more independently and deepening their disciplinary understandings. Teachers also saw benefits to their own pedagogy; specifically, they better understood students' learning processes and planned more attentively. This research suggests that committing to frequent writing integration can (1) enhance students' writing and disciplinary knowledge, and (2) enrich teacher knowledge related to supporting students' writing practices and using writing as a tool for learning in the content areas. Our findings also highlight the complex relationship between teacher beliefs and teacher practice. By looking at the instructional decision making of teachers who integrate writing frequently, we offer guidance on how pre- and in-service teachers might use reflection in and on action to develop a commitment to writing instruction.
\end{abstract}

Keywords: Writing in the content areas, literacy across the disciplines, writing instruction, secondary education, instructional decision making

\section{$\$ WRITING RESEARCH}

Carter, H., \& Townsend, D. R. (2022). A rationale for integrating writing into secondary content area classrooms: Perspectives from teachers who experience the benefits of integrating writing frequently. Journal of Writing Research, 13(3), 329-365.

https://doi.org/10.17239/jowr-2022.13.03.01

Contact: Hannah Carter, Department of Literacy, Language, and Culture, ED-LLC 513, Boise State University, 1910 University Drive, Boise, ID 83725-1725 | USA - hcarter@boisestate.edu. Copyright: Earli | This article is published under Creative Commons AttributionNoncommercial-No Derivative Works 3.0 Unported license. 
"Using writing is hard. I'll admit I don't like it, but this year more than ever, I've seen how tremendously it impacts student outcomes, and it's worth the time I put in. The students can see it too." - Jennifer

In the interview excerpt above, Jennifer described her commitment to and her feelings about using writing in her Biology courses. Later in this interview, Jennifer noted that her increased use of writing began as she attempted to adhere to the changing institutional expectations for literacy in her science department. She continued integrating writing, however, for different reasons. Jennifer spoke of her realization over time that the benefits of frequent writing outweighed any challenges she faced with writing instruction.

The positive contributions of writing and, more specifically, writing in content area classrooms, are undisputed (Bangert-Drowns et al., 2004; Graham \& Hebert, 2010; Graham et al., 2020; Klein \& Boscolo, 2016; Meizlish et al., 2013; Reynolds et al., 2012). Research indicates that writing in the content areas can improve students' writing quality and enhance disciplinary learning, among other contributions. Despite these affordances, recent years have not shown increases in writing time or depth in the secondary classrooms of many countries, including the United States (Applebee \& Langer, 2011; Gilbert \& Graham, 2010; Graham, 2019; National Commission on Writing, 2003; Wyse \& Ferrari, 2015). Based on a five-year study of writing in the content areas in 260 U.S. schools, Applebee and Langer (2011) concluded the amount of time students spend writing is "distressingly low," with fewer than $8 \%$ of class time spent on writing (p.16). Further, only $19 \%$ of written work represented extended writing of a paragraph or more. In a later research synthesis, Graham's (2019) findings confirmed that the amount students write in secondary schools should be increased if students are to benefit from writing. Most educators agree that writing is important, yet this belief does not always make its way to practice. Thus, investigating secondary teachers' practice and instructional decision making related to writing is essential.

While teachers' perspectives and rationales are rarely included, research does document the type of writing and the amount of writing that takes place in secondary content area classrooms (Applebee \& Langer, 2009, 2011; Gillespie et al., 2014; Graham et al., 2014; Kiuhara et al., 2009). Factors that inhibit good writing instruction (e.g., time, teachers' preparation and beliefs, policy, etc.) are also known (Graham, 2019). The current study builds on this work, providing an in-depth look at the decision making of teachers who navigate those barriers and use writing as an essential part of their practice. With the aim of using teacher reflections to discern the reasons why they chose to integrate writing, this study looked at four secondary content area teachers who were employing meaningful writing routines on a frequent, often daily, basis. Teachers reflected on their practice over a 10-week academic quarter, which allowed us to highlight the experiences of teachers who were employing frequent writing, but who have different disciplinary expertise, 
backgrounds, and perceptions on learning and writing. Through their reflections, we explored the following research question: How do secondary teachers describe the commitment to frequent writing integration

\section{Conceptual Framework and Related Literature}

\subsection{Teacher Decision Making Related to Writing Integration}

In the current study, teachers reflected on their practice and perceptions related to sustained writing integration as a means of exploring their instructional decision making. Thus, to better understand why teachers who integrate writing frequently do so, we looked to the literature on teacher decision making (Borko, 2004; Ghanizadeh \& Moahfian, 2011). This body of literature considers the factors that contribute to teacher planning prior to instruction, responsiveness during instruction, and evaluation after instruction, as well as decisions related to creating a positive learning environment and assessing students. Each type of decision is multifaceted and involves identifying the desired end result, determining options that may lead to the result, and selecting the best option to achieve the desired result. The decisions teachers make around writing instruction are influenced by several factors, including how writing integration in their context is defined and perceived, as well as their beliefs, pedagogical content knowledge (PCK), and challenges faced. The current study seeks to understand teacher decision making related to writing within their unique contexts. Below, background on writing integration is provided to consider how writing integration is perceived and defined in specific contexts may impact teacher decision making. For example, Beach (1994) found that teachers had similar beliefs, but not all teachers taught in congruence with those beliefs and instead perhaps learned to act within the context of their principals' orientations and student characteristics.

\subsection{Writing Integration in Secondary Classrooms}

Writing across the curriculum (WAC) has been a part of postsecondary education in the United States and Canada since the 1970s (Thaiss \& Porter, 2010), as well as other parts of the world such as Latin America (Narváez-Cardona, 2016). Survey data from 2007-2010 showed that more than 50 countries include some type of WAC curriculum in their higher education systems (Thaiss, 2012). In the last several decades, examinations of adolescent literacy practice in the United States have illuminated the significance of an integrated approach to literacy and content area instruction in secondary schools (Applebee \& Langer, 2013; Bean, 2000; ILA, 2017). According to Shanahan and Shanahan (2008), the need for "advanced literacy in America's economic, social, and civic life" continues to increase (p. 56). Furthermore, the nation-wide U.S. implementation of the Common Core State Standards refocused attention to writing in the content areas within the K-12 
context (National Governors' Association Center for Best Practices [NGA] \& Council of Chief State School Officers [CCSSO], 2010). More specifically, students are expected to consistently write in each discipline for a range of tasks and audiences over shorter and extended time frames (NGA \& CCSSO, 2010). This shifting paradigm in U.S. secondary education recognizes a "shared responsibility" among all teachers to integrate literacy more strategically, including writing for a variety of purposes (National Council of Teachers of English, 2011; Thaiss \& Porter, 2010). Debates about these standards and about the intricacies of content area literacy integration (Collin, 2014), including how secondary teachers might define and approach writing in their classrooms, endure. However, some U.S.-based organizations, such as the National Writing Project (NWP) continue offering writing support to teachers across contexts (Whitney \& Sarraga-Lopez, 2019).

For the purpose of this study, which was situated in the U.S. public school system, writing integration was recognized as both informal, or "writing to learn" (Brozo \& Crain, 2017; Ray et al., 2016), and more formal, or "learning to write" (Mancho'n, 2011). Both have important implications in the content areas depending on the student learning outcome. Writing to learn allows for processing of and immediate reflections on disciplinary learning, while learning to write allows for opportunities to draft and revise discipline-specific written products. A third type of writing has also been suggested. According to the disciplinary writing framework created by Drew and colleagues (2017), a comprehensive approach to writing in secondary classrooms includes the following three components: (1) foundational composition, or writing to learn disciplinary content; (2) intermediate composition, or learning to write for general audiences; and (3) disciplinary composition, or learning to write in discipline-specific ways. However, the way a teacher perceives these components, and makes decisions around them, can be influenced by their context, as well as their beliefs and knowledge.

\subsection{Teacher Beliefs, Knowledge, and Challenges Related to Writing Integration}

Broadly, instructional decision making in secondary classrooms often revolves around a classroom culture defined by the teacher's beliefs (Jenkins, 2018). Studies show that preservice and in-service teachers' beliefs about knowing relate to their beliefs about learning, and these epistemological beliefs relate to instructional decisions (McCarthey \& Mkhize, 2013; Neely, 2014). Regarding writing instruction, teachers' theoretical orientations, or their perspectives on the nature of knowledge, learning, and instruction within a specific discipline, can impact their teaching (Moje, 2015; Troia et al., 2011). Both the amount and quality of writing instruction present in content area classrooms has been predicted by teachers' preparation, self-efficacy, and beliefs (Gillespie et al., 2014; Gilbert \& Graham, 2010). Survey data from a year-long study in an urban elementary school showed that teachers had a 
stable sense of teaching efficacy and viewed writing instruction as important. These beliefs were explicitly tied to their practice. For example, teachers with higher levels of perceived teaching competence generally executed more research-based writing practices. Similarly, Berry (2006) found that teachers adapted their writing instruction in ways that connected with their implicit theories about teaching, learning, and disability. While the relationship between beliefs and actions is deemed as cause-effect, Yang (2015) suggests that this relationship may be reciprocal. In other words, beliefs and practices inform each other.

Beliefs, then, can influence if a teacher finds writing to be a relevant aspect of secondary classrooms (Jenkins, 2018), and writing practice may affect teacher beliefs about writing. Thus, the relationship between beliefs about writing and writing instruction may be an especially important consideration when looking at writing in the content areas. Content area teachers are often apprehensive about any form of literacy integration (Cantrell \& Callaway, 2008; Fisher \& Ivey, 2005; Tschannen-Moran et al. 1998) and are unsure how to promote positivity or respond to negativity related to students' affect around writing (Wilcox \& Jeffrey, 2015). The ability of a teacher to include writing and writing instruction in a classroom with efficacy and success depends on the teacher's beliefs and attitudes about writing, as well as their capacity to develop instructional activities (Daisy, 2009). Subsequently, pedagogical content knowledge (PCK) related to literacy, and more specifically, writing, plays a significant role in the teacher decision making of secondary content area teachers. PCK is the culmination of a teacher's content knowledge and their knowledge of strategic ways to teach that content (Shulman, 1986). Expert teachers who have a deep understanding of their discipline also have a cognitive roadmap to guide their instructional decisions (Lillge, 2012).

While research documents the relationship between teacher beliefs, PCK, instructional decision making, and practice related to writing, findings are not conclusive. Some studies show a misalignment between teachers' beliefs and their practice. Phipps and Borg (2009) and Li and Walsh (2011) studied teachers in Turkey and China, respectively. They identified tensions between teachers' beliefs about teaching grammar and technology and their related instruction. In other words, the teachers had specific beliefs about learning that conflicted with their observed practice. Similarly, even many teachers who believe that writing promotes students' learning of content knowledge spend little time on student writing (Applebee \& Langer, 2011). This mismatch may be related to systemic constraints. Troia and Maddox (2004) identified several other challenges to delivering effective writing instruction that likely also impact instructional decision making: (a) expansive subject content, (b) large class sizes, (c) variation in students' abilities, (d) decreased student motivation, (e) meeting the needs of many students, and (f) ineffective district-mandated writing curriculum. 


\subsection{Impact of Writing Integration on Student Learning}

Integrating writing and content area learning is important due to the impact on students' writing abilities, disciplinary understanding, and disciplinary skill development. The quality and frequency of writing integration in the content areas can positively influence a student's writing capabilities. Evidence-based practices such as explicit isolated strategy instruction, process writing, integrated practice with skills and knowledge in embedded activities, and the use of writing as a social process (Graham \& Perin, 2007; Klein \& Boscolo, 2016), have been shown to significantly improve adolescents' writing quality across content areas. Relatedly, studies on science writing have found writing improvement when teachers support students with writing for different purposes (e.g., inform or persuade) and using different genres (e.g., lab reports or research articles) (Hand \& Prain, 2002). Both the use of evidence-based practices and an increase in writing frequency can make a difference. According to Lawrence and colleagues (2013), teachers should "consider daily writing practice to be the diet that prepares novice writers to produce the analytic writing genres indicative of each discipline" (p. 9). Findings from true and quasi-experiments suggest that students become better writers by writing frequently (Graham et al., 2012). Just a modest increase in the amount students write-about 45 minutes per week-can enhance students' reading and writing performance (Graham \& Hebert, 2010; Graham, Harris, \& Santangelo, 2015). For example, Graham et al. (2016) found that the quality of students' written text was improved based on the amount of time students spent writing and the variety of purposes for which they wrote. In addition to increasing writing proficiency, writing integration is also a tool for promoting students' disciplinary learning (Gabriel \& Dostal, 2015) and engagement in each discipline (Graham et al., 2020; Klein \& Boscolo, 2016; Rivard, 1994).

A review explaining trends in writing to learn research described the effects of writing on learning as reliable (Klein \& Boscolo, 2016). In a more recent metaanalysis of 56 studies, writing about content reliably enhanced learning (effect size $d=0.30$ ), with equal effectiveness at improving learning in science, social studies, and mathematics, across all grade levels (Graham et. al, 2020). This may be even more true for students who lack writing motivation or who struggle with disciplinary content (Wright et al., 2019). Writing can promote disciplinary understanding in the initial stages of the learning process by aiding students with drawing on what they already know (Applebee \& Langer, 2013) and gathering and transmitting new information (Graham et al. 2012). Further, writing can internalize and deepen students' disciplinary knowledge (Graham et al., 2020). Examples include explaining concepts (Powell et al., 2017), exploring unexamined assumptions, having ideas available for evaluation (Graham et al. 2012), and reflecting on learning (Applebee \& Langer, 2013). Survey data from over 70,000 university students revealed that frequent and targeted writing resulted in higher- 
order, integrative, and reflective learning (Anderson et al., 2017). In content area classrooms, skilled writers are also more adept at using writing to extend learning, such as to make connections across learned content (Graham et al. 2012), than their peers who struggle with writing (Graham, 2007; Reynolds et al., 2012). For students ranging from elementary school (Klein \& Kilpatrick, 2010) to university (Luna et al., 2020), the quality of argument writing improved related to integrating multiple perspectives and accounted for posttest knowledge on the same topics. Similarly, Sampson and colleagues (2013) discovered that when middle and high school students had opportunities to practice authentic science-specific writing tasks and receive feedback on their writing, gains in both writing quality and science knowledge were seen. Perhaps most notable, fifth graders who received a writing intervention during new science and history units reached a deeper conceptual understanding in each individual discipline, as well as more advanced metaconceptual awareness of their learning (Boscolo \& Mason, 2001). These results suggest that even young learners can transfer writing skills across contents to enhance their learning and their understanding of each discipline.

Writing can also help students understand the uniqueness of each discipline and develop discipline-specific skills. The writing process makes student thinking visible (Biggs \& Tang, 2011; Hattie, 2009; Reynolds et al., 2012) and allows students to apply their disciplinary knowledge. This offers pedagogical benefits to teachers related to assessing student learning and development (Hand \& Prain, 2002). Through writing, students can practice thinking like disciplinary experts (Corcelles \& Castello, 2017; Meizlish et al., 2013), considering the unique language demands of each discipline (Townsend et al., 2020; Wallace et al., 2004), and discussing discipline-specific information (Boscolo \& Mason, 2001). Several studies with undergraduate Biology students highlight ways that writing enhances disciplinary skill (Quitadamo \& Kurtz, 2007; Quitadamo et al., 2008). Students' scientific writing (e.g., lab reports and inquiry-based writing) significantly improved their inference, evaluation, and analysis skills and was related to their critical thinking skills. Similarly, source-based writing tasks have improved adolescents' historical thinking skills. In a recent study, $31 \%$ of variance in the overall historical quality of students' writing (i.e., students' complex, contextualized historical thinking) was explained by engaging in source-based writing tasks (Monte-Sano \& De La Paz, 2012). van Drie, Braaksma, and van Boxtel (2015) also found that discipline-specific writing instruction improved the use of meta-concepts, one aspect of historical reasoning, by 11th grade students. Overall, according to Klein and Boscolo's (2016) research synthesis, writing helps students develop forms of reasoning specific to given disciplines, understand reflective learning in the professions, and begin to form their professional identity.

In sum, research points to writing in the content areas as benefiting students in several ways (Bangert-Drowns et al., 2004; Graham \& Perin, 2007; Graham \& Hebert, 
2010; Reynolds et al., 2012. However, writing research across different grade levels has also shown varying results related to what factors may influence the effectiveness of writing and writing instruction in promoting students' writing skill and disciplinary understanding. Various outside of school circumstances (e.g., poverty, genetics, biological functioning, Graham, 2018) can impact how writing plays a role in student learning. Additionally, grade level, minutes per in-class writing task, and presence of metacognitive prompts moderated the effects of writing on learning in Bangert-Drowns and colleagues' (2004) meta-analysis of writing to learn interventions in first grade through college classes. On the other hand, Graham et al. (2020) meta-analysis found that the effectiveness of writing to learn was not influenced by the features of writing activities, instruction, or assessment, for grades 1-12. In other words, while it is clear that writing to learn tasks result in positive learning gains, it appears there is no one correct way to facilitate those tasks, and many children do not receive the writing instruction at school that they deserve or need (Graham, 2019). Investigating how teachers who do integrate writing plan their instruction and reflect on students' responses, the goal of the current study, can be instructive for teachers and teacher educators, potentially resulting in more equitable experiences with writing in K-12 settings.

\section{The Current Study}

Previous research depicts the type and amount of writing that takes place in secondary content area classrooms (Applebee \& Langer, 2009, 2011; Gillespie, Graham, Kiuhara, \& Hebert, 2014; Graham, Capizzi, Harris, Hebert, \& Morphy, 2014; Kiuhara, Graham, \& Hawken, 2009), as well as factors that may inhibit good writing instruction (Graham, 2019). However, most of these studies include surveys about writing practice (Gilbert \& Graham, 2010), with a few observational studies focused on examining writing practice (e.g., Applebee \& Langer, 2011). The current study extends these lines of inquiry, providing a more in-depth look at teachers' perspectives on why they value and use writing as an essential part of their practice. The primary aim of this study was to explore teacher reflections to discern the reasons why teachers chose to integrate writing. While the field offers research suggesting relationships between teachers' decision making and their writing practice, scarcely any research has involved content area teachers sharing their own decision-making processes as they engage in frequent writing integration. The purpose of this study, then, was to better understand the rationales behind secondary teachers' frequent writing integration. Learning from teachers themselves about how they decide what to do and when, and how they interpret students' responses, can provide essential information for both pre- and in-service teacher education. Therefore, the research question for this study was: How do secondary teachers describe the commitment to frequent writing integration? 


\section{Methodology and Methods}

Multicase study design ("collective case study" per Stake, 1995) was used in this study, as it honored the need to describe teachers' experiences within their distinct content areas and school contexts using a replication strategy. Case study research is used to obtain an in-depth understanding of a small number of individuals, problems, or situations. In this study, a case included one teacher and one focal class, in which writing was integrated frequently and reflected upon consistently. This design also allowed for exploring teacher decision making around writing integration without manipulating the classroom setting (Merriam, 2009; Yin, 2014). Focusing on the "why" of teachers' individual behaviors allowed for an exploration of the reasons behind teacher instructional decisions and an explanation based on teachers' reflections over time. Below, we outline our setting and participants, data collection, and data analysis.

\subsection{Setting and Participants}

The study took place in a large school district housed in a midsized city in the western U.S. The district included over 100 schools and over 66,000 students, $16 \%$ of whom were designated as English Language Learners (ELL) and 13\% of whom were on Individualized Educational Plans (IEPs), which are plans developed to support students who are receiving special education services (U.S. Department of Education Institute of Education Sciences, 2017). To allow for a representative snapshot of the teachers' practices, this study took place over one quarter, which was 10 weeks and approximately 50 instructional days.

\section{Teacher Selection}

Purposeful sampling methods were used to identify teacher participants representing "information-rich" cases (Palinkas et al. 2015, p. 534). Working with teachers who prioritized writing was the main goal of recruitment; thus, teachers known from previous literacy-related initiatives were contacted. This allowed us to describe teacher perspectives who were committed to and frequently integrating writing. Four secondary teachers, each representing a different primary content area and working at a different school in the district, were chosen to provide multiple perspectives from different contexts. Our inclusion criteria were that teachers:

- Expressed commitment to frequent writing integration, with the goal to integrate writing daily;

- Set specific goals for writing integration;

- Taught in one of the four primary content areas;

- Had three or more years of teaching.

The teachers, their focal classes, and their goals for writing are listed in Table 1. 
Table 1. Teacher descriptions

\begin{tabular}{|c|c|c|c|c|c|c|}
\hline Teacher & $\begin{array}{c}\text { Content } \\
\text { Area }\end{array}$ & Focal Course & Experience* & Degree(s) held & Plans/Goals for the Writing in the Upcoming Quarter & Typical Way Writing was Integrated \\
\hline Jennifer & Science & Biology I & $17(7)$ & $\begin{array}{l}\text { Bachelor's in Biology } \\
\text { Master's in Secondary } \\
\text { Education }\end{array}$ & $\begin{array}{l}\text { "My goal for the year is a combination of increasing the amount of } \\
\text { writing students do regularly and increasing the depth of their } \\
\text { writing." }\end{array}$ & $\begin{array}{l}\text {-Working on projects that involved students } \\
\text { applying what they learned by using writing } \\
\text { and images } \\
\text { - Having students apply content knowledge } \\
\text { to unfamiliar situations through writing }\end{array}$ \\
\hline Ashley & Math & $\begin{array}{l}\text { Precalculus } \\
\text { with } \\
\text { Trigonometry }\end{array}$ & $7(4)$ & $\begin{array}{l}\text { Bachelor's in Secondary } \\
\text { Education } \\
\text { (Mathematics) } \\
\text { Master's in Secondary } \\
\text { Education }\end{array}$ & $\begin{array}{l}\text { "My goal is to both increase the amount of writing I integrate, } \\
\text { especially as I have never taught this subject before, and also add } \\
\text { depth to students' writing. In math, there often isn't any writing at } \\
\text { all! I also hope to focus on using more writing, not just discussion to } \\
\text { have students explaining why, in addition to being able to work out } \\
\text { problems. I also want to use writing for the small things." }\end{array}$ & $\begin{array}{l}\text { - Describing the steps for how to graph } \\
\text { functions before and after the graphing } \\
\text { process } \\
\text { - Using writing to explain why, not just be } \\
\text { able to work problems } \\
\text { - }\end{array}$ \\
\hline Brittany & English & $\begin{array}{l}\text { Honors } \\
\text { American } \\
\text { Studies } \\
\text { (English) }\end{array}$ & $5(5)$ & $\begin{array}{l}\text { Bachelor's in Secondary } \\
\text { Education (English) } \\
\text { Master's in Literacy } \\
\text { Studies }\end{array}$ & $\begin{array}{l}\text { "My goal this year is to add depth to my writing instruction. I want to } \\
\text { maintain the amount of writing I do with my classes but deepen the } \\
\text { intensity and the length of students' writing. I'm also thinking of } \\
\text { giving a prompt towards the beginning of the year to see where } \\
\text { students are at and letting their performance guide our planning } \\
\text { throughout the term." }\end{array}$ & $\begin{array}{l}\text { - Making connections between history and } \\
\text { literature in their writing } \\
\text { - Having students explore content through a } \\
\text { variety of writing tasks such as podcast } \\
\text { scripts, research proposals, and outlines }\end{array}$ \\
\hline Craig & $\begin{array}{l}\text { Social } \\
\text { Studies }\end{array}$ & $\begin{array}{l}\text { Advanced } \\
\text { Placement } \\
\text { U.S. History }\end{array}$ & $15(7)$ & $\begin{array}{l}\text { Bachelor's in Secondary } \\
\text { Education (Social } \\
\text { Studies) } \\
\text { Master's in Secondary } \\
\text { Education }\end{array}$ & $\begin{array}{l}\text { "My kids would benefit from more writing and depth followed up } \\
\text { with a lot more feedback. My goal is to sustain the writing I have } \\
\text { established in years past, but also to integrate better/quicker } \\
\text { feedback to my students. Reading and providing meaningful } \\
\text { feedback is difficult in an AP class, but it needs to be done in order } \\
\text { for students to grow. I need to have a clearer picture in my mind at } \\
\text { the beginning for what this will look like." }\end{array}$ & $\begin{array}{l}\text { - Engaging in small group discussions and } \\
\text { collaborative writing } \\
\text { - Practicing the use of writing to inform and } \\
\text { convince other people }\end{array}$ \\
\hline
\end{tabular}

*Note: Experience is shown as total years, with years in focal class in parenthesis. 
Also, a few notes describing typical ways writing was integrated into the teachers' classrooms are included. Each teacher felt they used writing daily in some capacity but hoped to use writing more meaningfully or more often. Thus, the term "frequent" is used throughout this paper to depict the participants' daily goals for writing integration.

\subsection{Data Collection and Analysis}

Several techniques were employed to establish trustworthiness in this study. We conducted the study throughout a full academic quarter of teaching and learning. Through extended time with the teachers, and through looking at teachers in different districts, our data collection was robust and included representation of different teaching contexts. Additionally, purposive sampling and thick description of each case promote transferability. We also gathered data systematically from a variety of sources over time. To ensure credibility, we detail the steps taken during data collection and analysis below (Yin, 2014). Further, the researchers met regularly to discuss emergent findings during data collection and analysis. We also reviewed the themes independently throughout data analysis to ensure representation of the data set. We recognize that our data are drawn from reflections and interviews, meaning findings are drawn in large part from self-report. However, we triangulated teachers' perspectives by looking at their reflections from multiple points throughout the semester, including before the semester began, weekly during the semester, and at the conclusion of the semester. Despite the potential limitations of self-reported data (Shavelson, Webb, \& Burstein, 1986), having teachers consistently reflect throughout the semester provided the most authentic picture of teachers' instructional decision making while they were frequently integrating writing.

\section{Data Sources}

Consistent with case study design, multiple data sources were collected for each teacher with the purpose of documenting decision making (Yin, 2014). Data collection was designed to encourage teachers to engage in authentic reflection around their decision-making processes that were rooted in concrete experiences via daily instructional logs and observed lessons. Reflection-in-action, or reflecting on behavior as it happens, allowed teachers to consider what they were thinking, feeling, and doing as they integrated writing (Schon, 1983) and why they were making these choices. Teachers reflected on their practice weekly, monthly, and at other increments throughout the quarter. Data collection (described in Table 2) began with a pre-term qualitative survey to document teachers' perceptions about writing integration and about the writing climate of previous courses taught. Preterm meetings included discussions of the teachers' goals and plans for writing over the upcoming quarter. When the term began, teachers documented their daily 
practice by submitting instructional logs that included 1.) the type of writing students engaged in; 2.) a description of the instruction provided for that writing; 3.) the amount of time spent on student writing and related instruction; and 4.) the purpose for instructional decisions around writing.

Table 2. Data Collection

\begin{tabular}{|c|c|c|c|c|}
\hline & Type of Data & Description of Teacher Participation & $\begin{array}{c}\text { Per } \\
\text { Teacher }\end{array}$ & Total \\
\hline 1 & $\begin{array}{c}\text { Pre-Quarter Meeting } \\
\text { Notes }\end{array}$ & $\begin{array}{l}\text { Described goals and } \\
\text { plans for quarter }\end{array}$ & 1 & 4 \\
\hline 2 & Open-Ended Surveys & $\begin{array}{l}\text { Documented writing climate and } \\
\text { teacher perceptions (Beginning, } \\
\text { middle, and end of quarter) }\end{array}$ & 3 & 12 \\
\hline 3 & $\begin{array}{l}\text { Daily Instructional } \\
\text { Logs }\end{array}$ & $\begin{array}{l}\text { Submitted weekly to explain daily } \\
\text { writing integration }\end{array}$ & 10 & 40 \\
\hline 4 & $\begin{array}{l}\text { Weekly Written } \\
\text { Reflections }\end{array}$ & $\begin{array}{l}\text { Reflected on daily } \\
\text { instructional logs }\end{array}$ & 10 & 40 \\
\hline 5 & $\begin{array}{l}\text { Weekly Journal } \\
\text { Prompt Responses }\end{array}$ & $\begin{array}{l}\text { Responded to prompt eliciting } \\
\text { reflection on the quarter more } \\
\text { broadly }\end{array}$ & 10 & 40 \\
\hline 6 & $\begin{array}{l}\text { Teaching Observation } \\
\text { Protocols/Notes }\end{array}$ & $\begin{array}{c}\text { Provided a point of } \\
\text { discussion/reflection for interviews } \\
\text { (Beginning, middle, and end of } \\
\text { quarter) }\end{array}$ & 3 & 12 \\
\hline 7 & $\begin{array}{l}\text { Individual In-Person } \\
\text { Interviews }\end{array}$ & $\begin{array}{l}\text { Reflected on observations (Beginning, } \\
\text { middle, and end of quarter) }\end{array}$ & 3 & 12 \\
\hline
\end{tabular}

\section{Data Analysis}

Data analysis involved a thematic approach (Braun \& Clarke, 2006), which allowed us to make sense of shared meanings and experiences (Braun \& Clarke, 2012). A multi-phase iterative process for thematic analysis, explained below, was employed that prioritized describing the teachers' decision making around integrated writing. The aim of this study was exploring teacher reflections to discern the reasons why teachers chose to integrate writing. To do so, we completed within-case and cross- 
case analyses to highlight both teachers' unique and collective reflections (Braun \& Clarke, 2012).

Within case analysis began with the familiarization phase (Braun \& Clarke, 2012). Participant case study tables (Miles \& Huberman, 1994) were created to compile teachers' experience and education, teaching assignments, and focal class descriptions. This provided the researchers a better understanding of the teachers and their contexts. Next, individual spreadsheets were created for each teacher to organize the data and document within-case noticings. The first iteration of data analysis included reading through each teacher's full data set to note commonalities for that teacher across data sources, identifying reasons for integrating writing that were mentioned in multiple data sources. Using a deductive approach, the researchers brought a set of ideas to the data (Braun \& Clarke, 2012) that were in alignment with Yang's (2015) view that beliefs and practice inform each other. Because our teachers were committed to frequent writing integration, we knew that evaluating their instructional decision making would allow us to discern reasons why they chose to integrate writing. With this, our coding focused on identifying the rationales that were described in teachers' reflections. In other words, each meaningful unit of data (e.g., segments such as phrases, sentences, or paragraphs) related to why teachers integrated writing was assigned a code. An open-ended approach to coding was used (Saldana, 2016) that was guided by the study aim of identifying reasons that teachers integrated writing. The data sources were considered line-by-line, and both teachers' latent and semantic statements were documented (Braun \& Clarke, 2012). More specifically, we included statements in which teachers overtly mentioned reasons (e.g., "I choose to use writing in this way because..."), as well as statements that alluded to reasoning. Codes took the form of one-word descriptive codes (e.g., "collaboration") and what Saldana (2016) refers to as "InVivo" codes, where phrases are taken directly from participants (e.g., "collaborative writing used as a support").

For cross case analyses, we created a master table. The coded data for each individual teacher was compared to find commonalities across teachers. In other words, we listed all the codes for each teacher to identify how the reasons teachers described for using writing were similar. Consistent with thematic analysis procedures, each data source was reviewed across all four teachers to determine cross-case themes (e.g., the surveys for all teachers were considered and later the journal prompt responses for all teachers were considered) (Braun \& Clarke, 2012). While the observations and instructional logs were reviewed, they were not coded, as the purpose for both was providing teachers with snapshots of their instruction on which to reflect. A total of 12 interview transcripts, 12 surveys, and 80 reflections and journal prompt responses were reviewed multiple times. After the data sources were saturated, as determined by no different codes emerging, all codes from the master table were closely compared and contrasted. It was apparent that teachers 
were explaining their rationales for writing as related to benefits for 1 . their students; or 2. themselves and their pedagogy. Thus, the data were organized around these two categories. To make sense of both the student benefits and the teacher benefits presented in the data, codes within each of these two primary categories were collapsed (Saldana, 2016), leaving the following cross-case themes: 1. increased independence on writing tasks; 2 . increased disciplinary understandings; 3 . better understanding of learning processes; 4 . more attentive planning.

In the final phase of analysis, we read and reread the four case studies numerous times to further consider cross-case findings. We returned to the within case analyses to confirm that cross-case themes did indeed capture the unique reasons teachers provided for integrating writing. Creating an outline of potential findings that included participant quotes and counterevidence helped us to confirm the cross-case findings. Table 3 below is an abbreviated representation of this process and includes representative ideas from each teacher not represented elsewhere to better illustrate the themes. Because the teachers reflected in a variety of ways over an extended period, a number of outlier categories emerged from their reflections, such as their opinions about high-stakes assessments and their past experiences as writers. As a principle of thematic analysis, Braun and Clarke (2012), these categories were removed, as they were deemed unimportant to the research question being studied.

\section{Within Case Findings - Writing Rationales from Each Content Area Teacher}

The aim of this study was to explore teacher reflections to determine why teachers integrate writing frequently. This study's primary finding was that teachers described a myriad of benefits that impacted their decision to frequently integrate writing. When explaining their rationales for integrating writing frequently, the teachers' reflections centered on student and pedagogical benefits, as leading contributors to their writing integration. In other words, teachers were making decisions to amplify the benefits of integrating writing. Teachers found that writing integration led to increased independence on writing tasks and increased disciplinary understandings, as well as a better understanding of student learning processes and more attentive planning. While each of the teachers were committed to writing integration, each teachers' instructional decision making related to frequent writing offers unique takeaways. Each teacher approached writing differently based on what they felt was appropriate for their students and their content area. Thus, our findings first report the reasons described by each content area teacher for integrating writing, including their perspectives on student benefits and pedagogical benefits. Later, we look across the teachers' reflections to investigate cross-case themes. 


\subsection{Biology I - Jennifer}

Jennifer explained several benefits of daily writing that she recognized in her Biology course - connections between concepts and processes, increased willingness to write, analysis of challenging discipline-specific texts, and opportunities for differentiation and scaffolding.

\section{Student Benefits of Frequent Writing That Guided Teacher Decision Making}

When asked to describe if and how she felt daily writing was impacting her students over the quarter, Jennifer mentioned students' increasing Biology knowledge. Jennifer found that through their writing, her students "better comprehend[ed] content," as they engaged in thoroughly analyzing concepts and processes and making connections between them, which made Biology "less foreign." Later in the quarter, when reviewing the writing portion of her Student Learning Objectives (SLO) Assessment, Jennifer mentioned a "crying moment" when she noticed the students' application of content knowledge and connection-making across concepts:

At the end of the term, they had to write an essay about why we have excess carbon in the atmosphere and how humans made it that way. Some students went into full detail about the carbon cycle and all the processes humans are engaging in, such as burning fossil fuels and burning forests. Their explanations showed a very high-level understanding of climate change...I was very impressed with the various concepts analyzed but also the environmental implications explained. I taught each of these pieces separately, but they really brought it all together for me in their writing. I would say three fourths of my students got full credit, and it was a crying moment.

In addition to being pleased with students' analysis in their writing, on several occasions throughout the term, Jennifer perceived that her students had an increased willingness to "just get out the paper and write." She mentioned this as she reflected on her students' writing over the 10-week period:

They grew during the first quarter...The more that I worked with them, I noticed that when I gave them paper and asked for a few lines, or when I asked them to write a few paragraphs on a test, they could do it. We gradually built up to that. They knew they had to write, and it became ok... The growth just from one month to the next is pretty cool.

At the conclusion of the quarter, Jennifer was enthusiastic in reporting that her students were producing academic texts in Biology more independently.

Jennifer also attributed her students' analysis of challenging discipline-specific texts to their frequent writing about Biology. More specifically, Jennifer predicted 
the improvements were a result of the additional exposure to and practice with science vocabulary through their writing. She felt that because the academic vocabulary in science is such an important aspect of disciplinary understanding, students' use of vocabulary promoted their understanding of science terms. Jennifer stated,

It's the application of academic vocabulary that makes the difference...They recognize and understand academic vocabulary words better. They don't look so lost during lecture. If we discuss genetics, for example, this can be environmentally changed. This phenotype can be environmentally modified. They are able to make those meaningful connections between the academic terms.

Writing was also a way to have students relate science concepts to the real world, to their lives, and to new and unfamiliar situations, which ultimately led to deeper application of the content. One example of this was her use of songs. Students listened to and read the lyrics of various songs, and then wrote about and analyzed Biology concepts. "Big Yellow Taxi" by Joni Mitchell, for example, allowed students to explore environmental issues. Another aspect of writing important to Jennifer was ensuring that students had choice and used a combination of writing and images to portray meaning.

\section{Pedagogical Benefits of Frequent Writing That Guided Teacher Decision Making}

Using writing frequently was also a way to seamlessly differentiate and scaffold to promote students' disciplinary understandings. One specific writing assignment that Jennifer's students engaged in had the purpose of explaining symbiosis. Students completed this writing after having taken notes, watched a video, and written in their science journals about the concepts. She provided options for students to show what they knew that included a poster, a news article, and a short story. Students also chose one of three types of symbiosis to focus on, while still attending to the other two in their writing. They worked individually but were allowed to complete online research from their phones and use their notes to support their writing.

In addition to using writing as a scaffold, Jennifer had also shifted her writing purposes from "more basic recall" in previous years to having students explain, describe, and apply their knowledge through writing. Jennifer considered writing imperative to assessment because she admitted that speaking with every single student as regularly as she hoped to assess them was simply unrealistic. She could, however, evaluate their understanding through writing, which was concurrently reinforcing their learning. Jennifer also admitted that talking to each student individually everyday was not feasible, but having students write for formative 
assessments helped her feel more comfortable about student progress. Moreover, after reviewing student writing, Jennifer was able to grasp what concepts to revisit. Daily writing led Jennifer to understanding her students' needs better than she ever had, as she demonstrates below:

Researcher. Your use of writing on assessments...Do you think that's been similar or different to other years in Biology?

Jennifer. I'm doing a lot more formative assessments this year than I ever have before. I'm trying to pick it up quickly, and it's leading to a lot more work and struggle on my part, but I think I know the kids a lot better than I ever have. And I can go over to a student and not only know who they are but know a little bit about how they think. So I can give them-- like even write down a little guide for them on the side of their paper to help them think about things.

\subsection{Precalculus with Trigonometry - Ashley}

In her math course, Ashley felt that students learning concepts beyond memorization and having awareness of their thinking throughout the learning process, as well as understanding Precalculus, were benefits of frequent writing. She also found writing both as a useful instructional support and an assessment tool.

\section{Student Benefits of Frequent Writing That Guided Teacher Decisions Making}

Ashley described her frequent use of writing as supporting students in thinking more deeply about math concepts. This transition of moving students beyond memorization, to understanding what they were doing, as well as how and why, was the impetus for Ashley's writing integration. She believed that writing forced students to contemplate concepts on a deeper level and helped them understand "what it meant to explain in math and not just show." She detailed the most meaningful writing of the semester as when students had to describe, in detail, how to graph a polynomial function without actually graphing the function. She felt this "really got them thinking about what I was asking them to do and what it meant to graph, to actually execute that skill."

When talking about pushing students to think more deeply, Ashley recounted how some students were displeased with the writing on their first test, as well as her feedback, because they were accustomed to only being held accountable for solving the problems, with no expectation of explanations:

I noticed with some of these other questions, like the horizontal asymptote especially, they just-- some of them just memorize. So I would be like, 'Well, what do $\mathrm{N}$ and $\mathrm{M}$ actually stand for?' And some of them did explain it. But 
it was interesting, because some of them just put the letters, and I wrote, 'I don't know what that means.' And so some of them kind of got mad at that. But I said, 'Well, you're not telling me what $\mathrm{N}$ and $\mathrm{M}$ actually are. They could be anything.' And so, I think for them, too, it allowed them to see, 'Oh, I have to be more specific in what I write.'

Later in the semester, Ashley noticed her students' willingness to write. When the quarter concluded, she reflected, "Students definitely didn't want to 'write in math.' Once they realized it wasn't going away, they stopped complaining and were able to do it." Her students became "used to the writing that [she was] asking of them." Ashley also detailed the way students wrote about the concepts they were learning in class; she noted their level of detail, which she perceived as becoming more substantial over the quarter as they continued to write frequently.

Pushing students' thought processes before, during, and after their problem solving was also an affordance of frequent writing for Ashley. Over the quarter, she experimented with integrating writing at various points in her lessons to promote disciplinary understanding. When describing her students' understanding of asymptotes, she spoke about the efficacy of having students explain the concept in writing first, before they moved on to practice problems:

The one where they had to explain their asymptotes, $90 \%$ of them did the problem correctly if they could explain the idea correctly first. Which is really good because asymptotes are a hard thing for kids to grasp. This is why we really wanted to get them thinking about it and putting it in their own words first.

Another example Ashley reported was a quotation mingle. Students first described in writing how to graph a polynomial function, and then as they constructed the graph, they verbally explained the process to another student, or "mingled." She believed that writing about math concepts was a precursor to executing problems correctly, as she found that being able to write about concepts usually meant students could also correctly apply those concepts. Additionally, Ashley utilized writing after problem solving to have students reflect on their own learning. While she found student self-assessments to be helpful, she considered them an empowering exercise for her students as well: "If nothing else, even if I don't get much out of it, they got something out of it, which is really what it's about. It was about them reflecting on their mathematical practice and their tests." Another way she empowered students to engage with math language was presenting to the class. She stated that students would learn and better remember the content "if they're teaching it and they're making the connections...that's where the discussions and the writing and the explaining, all of that comes together." 


\section{Pedagogical Benefits of Frequent Writing That Guided Teacher Decision Making}

In discussions about including writing both as an instructional support and an assessment tool, Ashley found the use of writing valuable to her own understanding of students' learning. She stated that writing clarified the way students were thinking about and understanding Precalculus. She provided an example of how useful seeing students' thought process through their writing was to her:

It's really interesting for me to see how their thought process works. Because there's the way I explain it, but some of them take it and internalize it differently. Which is not wrong...And then, it's funny seeing how more indepth-- you can tell how their different brains work-- because some of them will go more in-depth. Some of them will bullet. Some of them will number, like, 'First I did this, then I did this.' I like it because I really get to see how they make connections. And some of the connections-- our asymptote problems, some of them got them mixed up.

More specifically, by using their writing to have a clearer understanding of the students' thinking, Ashley was able to parse out the nuances of their comprehension of math concepts. If students had only memorized certain steps, for example, or if they had mastery of applying the concept in various situations, it became clear through their writing. This allowed her to target where students had made connections and "where [she] could get their thinking to go deeper." An example was one quiz in which students demonstrated their understanding of whether a relation was a function. Looking at the parts of the definition students connected to in their written responses, Ashley was able to attend to misconceptions.

Another pedagogical benefit of daily writing that Ashley mentioned was finding herself more aware than ever of the writing used in her lessons. After integrating writing daily for an extended period, she found herself more conscious of continually trying to find new, additional ways to add more writing to her instruction. She felt that heightened awareness led to more conscious and purposeful instructional decision making. The more she was using writing, the more attentively she contemplated the "how" related to her writing use. Ashley strived to ensure that she was not only having students write often but was having them write to serve specific disciplinary purposes. She admitted this "seamless integration" was a challenge, but she never wanted to approach writing in a way that left students "not understanding the why or making the connection themselves." 


\subsection{American Studies (English) - Brittany}

Through consistent writing practice, students were working towards the overarching disciplinary goals for Brittany's course, which she explained as hinging on the interconnectedness of literature and history. Brittany worked to equalize the time her students spent using writing to internalize content from literature and history and the time students spent developing as writers. She interpreted the first portion of the quarter as focused on writing to learn "since students are using writing to show me what they know/understand about the content". With a formal essay following that week, she described an upcoming shift in her writing focus to learning to write. She closed this reflection stating, "I'm hoping to find more balance between the two." This balance was challenging with the number of texts that were a necessary part of her course.

Analyzing texts meant that response to literature was a recurring way that Brittany's students engaged in writing. A few weeks into the quarter, she explained what she felt like was a causal relationship between her students' writing and reading performance:

Anecdotally I saw a connection between students' reading and writing, especially when compared to the beginning of the year. Most students improved in their ability to write a claim about a text and support it with evidence from the text.

By improving in their claim writing and use of evidence from texts, Brittany's students continued to analyze and understand challenging texts in American Studies. According to Brittany, by the end of the quarter, her students were negotiating the challenging texts she presented them, as they continued writing both collaboratively and independently in response to the texts. In one of her interviews, Brittany stated, "It was exciting because they're hard texts and to be able to do that with them, especially with Colonial and Puritan time periods...They were able to begin to [analyze the texts] on their own." Brittany valued that through writing, students explored texts more deeply. Subsequently, she felt their understanding of disciplinary concepts was strengthened by and through the act of writing.

Brittany also discussed the power of having students write in a variety of forms, including more practical reasons that are rooted in real world purposes. She felt that the podcast script assignment her students completed was valuable for its practicality and the experience it gave them preparing a more formal proposal, on which they took time to fine tune their ideas. Brittany saw the value of having students write for the purpose of reacting to issues that were happening around them. She felt that connecting the texts to the world and to themselves, offered students opportunities to examine issues and be empowered by responding to them: 
I want them to understand that no text is written in a vacuum. The author is responding to something that happened in their life and in society and, therefore, is writing about it and hoping people will read it, and respond to it, and really think about those deep issues. So, I'm hoping that they can respond to the text through their own writing and put their two cents in.

Another benefit that Brittany saw of frequent writing was giving students time for free writing. Brittany realized that as her students read their student-chosen novels and freely responded in writing to those texts each day, they gradually produced lengthier and more in-depth responses. On a reflection toward the end of the quarter, Brittany indicated:

The biggest reward was seeing students enjoy reading their books and enjoy writing about them daily. I see a lot of kids writing longer and longer responses each day as they get into their books, which is really exciting to see.

\section{Pedagogical Benefits of Frequent Writing That Guided Teacher Decision Making}

Brittany felt that by having students write consistently, her repertoire of writing instruction expanded, and she had become more willing to take risks. According to Brittany,

Daily writing has made me more aware of the types of writing I use in my classroom and has helped me try to step out of my comfort zone and try newer ways of doing things. It has made me more mindful of what writing I value most in the classroom and what I want my students to be able to do by the end of the year.

Brittany's stronger awareness of her writing practice also caused her to plan more purposefully, "as opposed to just doing it because it's what I've always done." Daily writing made her aware of specific ways she wanted to improve her writing instruction. For example, at the beginning of the year she often felt like the writing she used was "...minimal on the DOK levels. However, as the year progressed, and we got deeper into American history, and I feel like the types of writing intensified." She later stated that using writing every day reminded her that quality and meaningful writing integration can be easier than she once thought.

\subsection{Advanced Placement (AP) U.S. History - Craig}

When reflecting on the benefits Craig saw play out as a result of frequent writing, he discussed students getting ample writing practice and gaining content knowledge. Daily writing also allowed Craig to better evaluate student writing and be more deliberate about his writing plans. 


\section{Student Benefits of Frequent Writing That Guided Teacher Decision Making}

In AP U.S. History, Craig saw daily writing as deepening disciplinary understandings in terms of pushing students in writing and in content. Craig felt the pressure to both teach content and writing skill and find unity amongst the two. He chose writing topics that would help students "authentically engage in deconstructing historians' work." In an early written reflection, Craig stated,

This week was learning to write, mostly format and technique. This will morph into more learning to write and writing to learn as the students will have to learn and write concurrently in the future.

He viewed writing as "a way of internalizing." One way this played out for his students was the connections they were making across time periods. After shifting from a focus on the multiple-choice portion of the AP exam last year to a more writing-rich approach this year, Craig noticed an increase in his students' content knowledge only three weeks into the quarter. Comparing the two, he revealed:

I feel like looking at the score reports and the analysis from the College Board, [last year's students] couldn't make the big connections to disparate areas of US history. This year, they write on every quiz, whereas, last year they never wrote on quizzes just because I was trying to get them ready, with a focus on multiple choice. So, this year you can already see them making bigger connections across time periods...So after that first quiz, they were like, oh. I've really got to know this stuff because this is different...

Craig mentioned another concrete example of this several weeks later. He had students write up a comparison, contemplating socioeconomic class, of Bacon's Rebellion and Shays' Rebellion, which are 100 years apart. He reflected: "Most of them did really well. I was pleased. This was a pretty challenging prompt and most of them got it. They've been doing a good job on their quizzes."

His focus on formal writing early in the quarter, and the use of daily writing, was in part driven by Craig's displeasure with AP exam scores from the previous year, and his quest to try out a new method in the current year. Craig stated that his decision to shift his practice this year to include more writing was driven by two assumptions - students needed more writing practice and students would gain content knowledge by writing more frequently. He stated that at the beginning of the year, "Some of my students could verbally express themselves at a higher level than they can when writing." However, he thought that daily writing led to students being able to articulate their ideas more willingly and capably in writing. 


\section{Pedagogical Benefits of Frequent Writing That Guided Teacher Decision Making}

Craig was continually searching for ways to better understand his students' learning processes as writers. He struggled with time constraints and the tension to find a manageable system for feedback and grading that was reasonable with the timeline of AP preparation. At the same time, his students desired frequent feedback. Efficient ways to track student writing over time was a common topic of discussion. He had various ideas for approaching this goal, but he questioned their efficacy based on the number of students in his four AP U.S. History sections (150). The daily use of writing allowed Craig to determine trends in his students' writing to explore in class, as well as realize gaps in the writing assignments themselves that may need attention. He adjusted his instruction to account for both.

Craig similarly described using writing daily as resulting in "more focused planning day to day." This focus then required him to be more creative in attempts to integrate writing each day. Craig slowly became more deliberate about his writing plans over the term as well, a goal he set early in the year. He thought of the quarter as a combination of the old and the new; he referred to "the old" as the requirements of the College Board for what his students were to be proficient in by May. "The new" was his formatting and sequence of instruction. According to Craig, he "made a more conscious effort this year to pre-plan how the different writing activities link together."

\section{Cross-Case Findings and Discussion}

The purpose of this multicase study was to explore secondary content area teachers' reflections, as related to their experiences with frequently integrating writing into content area lessons. More specifically, we looked to determine the reasons why teachers who integrate writing frequently do so. Previous research documents that many teachers value writing, but their writing practice is still sometimes limited (Applebee \& Langer, 2011; Graham et al., 2014). As evidenced by the within-case findings above, each of our teachers was invested in implementing frequent writing integration. The "routinization" of writing was nonnegotiable. Because of this, teachers were able to see the benefits of writing on a regular basis. Teachers reflected on distinct student benefits and pedagogical benefits that impacted their instructional decision making related to frequent writing. Below we describe themes from across the teachers' instructional decision making related to increased independence on writing tasks and increased disciplinary understandings, as well as a better understanding of student learning processes and more attentive planning. 


\subsection{Student Benefits of Frequent Writing That Guided Teacher Decision Making}

When looking at commonalities across the teachers' instructional decision making, their reflections highlighted the ways students benefited from writing frequently. The teachers' commitment to frequent writing integration was rooted in their realization that any negative or challenging associations they may have with writing were outweighed by the student benefits. While the teachers were each knowledgeable about research on the impacts of writing, their reflections documented that frequent writing itself increased their buy-in, as it allowed them to see and experience the student benefits. This suggests that teachers' theoretical orientations toward writing, or their perspectives on the nature of knowledge and learning (McCarthey \& Mkhize, 2013), may be more influential to their instructional decision making than other beliefs or knowledge related to writing. Each teacher had slightly different notions of learning related to understanding content, developing habits of mind, and enacting disciplinary practices, yet they all detailed explicit ways their writing integration afforded advantages to their students. Table 3 includes a few ways that frequent writing benefitted students. Students increased their independence on writing tasks and enhanced their disciplinary understandings. Teachers described these student benefits as influencing their decision to continue integrating writing.

\section{Increased Independence on Writing Tasks}

As our teachers integrated writing frequently and reflected on their practice, they found value in students' writing independence. Early in the quarter, teachers were asked about their students' writing skills in comparison to the expectations for writing in their courses. Each teacher only slightly agreed that their students were on par at the beginning of the year to perform adequately on writing tasks. However, over the quarter, the teachers reflected on their students' advancement with independent writing skills. Using frequent writing, teachers observed their students progressively take ownership of their writing as they developed independent writing skills throughout the quarter. This aligns with Gillespie and colleagues (2014) suggestion that writing can encourage a learner's autonomy.

Frequent writing integration meant that students were participating in writing routines during each class session. This suggests the teachers were engaging students in a range of tasks and audiences over shorter and extended time, as required by the CCSS (NGA \& CCSSO, 2010). These writing routines also helped legitimize writing for students. Despite the nature of the course (e.g., AP U.S. History versus Biology I), students slowly realized that writing was the norm. For example, Ashley's students realized this as they were required to show their understanding of mathematical concepts on assessments through writing (Hand \& Prain, 2002). 


\begin{tabular}{|c|c|c|}
\hline \multirow[b]{2}{*}{ Teacher } & \multicolumn{2}{|c|}{ Student Benefits of Frequent Writing } \\
\hline & $\begin{array}{c}\text { Increased Independence } \\
\text { on Writing Tasks }\end{array}$ & $\begin{array}{c}\text { Increased Disciplinary } \\
\text { Understandings }\end{array}$ \\
\hline Jennifer & $\begin{array}{l}\text { - Analyzing and synthesizing } \\
\text { concepts more independently } \\
\text { through writing } \\
\text { - Having more willingness to write } \\
\text { daily }\end{array}$ & $\begin{array}{l}\text { - Making connections between } \\
\text { concepts, real world applications, and } \\
\text { their personal lives } \\
\text { - Applying content knowledge as } \\
\text { they reflect and analyze through } \\
\text { writing }\end{array}$ \\
\hline Ashley & $\begin{array}{l}\text { - Improving the culture of writing in } \\
\text { a math class } \\
\text { - Engaging in writing routines in each } \\
\text { class session }\end{array}$ & $\begin{array}{l}\text { - Including clearer explanations of } \\
\text { problem solving through writing } \\
\text { - Describing how to graph functions } \\
\text { before and after graphing }\end{array}$ \\
\hline Brittany & $\begin{array}{l}\text { - Improving their ability to locate } \\
\text { evidence in texts they read } \\
\text { - Learning about a topic, creating a } \\
\text { product in response to it, and helping } \\
\text { their classmates better understand } \\
\text { the topic }\end{array}$ & $\begin{array}{l}\text { - Including depth and different } \\
\text { perspectives in their writing to } \\
\text { explain content } \\
\text { - Analyzing events and using } \\
\text { multiple primary source documents } \\
\text { when writing }\end{array}$ \\
\hline Craig & $\begin{array}{l}\text { - Developing dispositions of good } \\
\text { writers } \\
\text { - Becoming familiar with the AP } \\
\text { writing genre }\end{array}$ & $\begin{array}{l}\text { - Comparing socioeconomic class } \\
\text { across time through collaborative } \\
\text { writing } \\
\text { - Analytically categorizing content } \\
\text { primary source documents in their } \\
\text { writing }\end{array}$ \\
\hline
\end{tabular}

The culture of writing these teachers had established in their classes appeared to boost their students' willingness to write. Extending the previous finding that the amount of time students spent writing is related to the quality of their writing (Graham et al., 2016), frequent writing also led to students in this study producing written products with increasing levels of substance. Each teacher identified their students' writing as becoming longer (Brittany), more detailed (Ashley and Jennifer), or both (Craig). Frequent writing was valued by the teachers for its contribution to students' independent writing skills; yet teachers only minimally mentioned that daily writing better prepared students to write in ways similar to experts in their discipline (e.g., Quitadamo \& Kurtz, 2007; Quitadamo et al., 2008). This leaves us wondering how more discipline-specific writing was considered as part of teachers' decision making around writing and if teachers' continued use of 
frequent writing might contribute to a focus on apprenticing students into disciplinary writing (Moje, 2015). Despite teachers' rationales for using writing often lacking priority on expert writing practices, our teachers did find that writing enhanced students' disciplinary understandings.

\section{Increased Disciplinary Understandings}

Deepened disciplinary understanding was recognized by each of the four teachers as a benefit of daily writing. Like Graham and colleagues' (2020) meta-analysis findings, there were no perceived differences in the effectiveness of writing to improve student learning based on discipline or grade level in this study. However, building content knowledge was defined and approached in various ways by each teacher. Likewise, teachers leveraged writing differently and perceived distinctive student benefits of writing as related to their discipline. Jennifer and Brittany, for example, found writing to reinforce real world applications of their content. This instructional rationale alludes to the notion by Shanahan (2008) that to engage in U.S. economic, social, and civic life, students must understand how to engage in advanced literacy practices. Ashley and Craig, on the other hand, saw writing as a way of internalizing content more deeply, such as making connections across content learned (Graham et al. 2012) and reflecting on learning (Applebee \& Langer, 2013). Writing daily was valued as a means of learning for students in each teacher's classroom. Writing integration helped students learn new concepts and ideas with more depth. In addition to developing stronger conceptual knowledge of the important concepts in each content area, our teachers noticed their students were able to make more meaningful connections between those concepts, as well as more meaningfully engage with disciplinary texts.

Teachers witnessed their students deepening their understanding of disciplinary content, contexts, and texts. This finding is similar to intervention studies showing that through writing tasks, a student's ability to engage in disciplinary practices, such as rhetoric, improves (Wright, et al., 2019). Additionally, Graham and Herbert (2010) found that writing about content improves students' reading comprehension, reading fluency, and word reading. Brittany attributed her students engaging more deeply with disciplinary texts, in part, to her students' practice with claims and evidence and their writing. Similarly, Van Drie and colleagues (2015) found that discipline-specific writing instruction improved students' historical reasoning. Jennifer explained her students' application of discipline-specific vocabulary in their writing as building a bridge to their understanding of disciplinary texts. The teachers recognized that, when students frequently wrote about concepts and texts, their understanding and analyses became more robust. Teachers recognized the role of disciplinary vocabulary in disciplinary learning (Townsend et al., 2020), and felt their students' application of vocabulary when writing promoted their understanding of disciplinary concepts 
and subsequently disciplinary texts. This finding extends previous research on writing to learn, which has in part confirmed students' ability to simply reproduce knowledge. Further, teacher survey data collected across the U.S. showed that while more than half of teachers applied a number of writing to learn strategies monthly, few teachers directly taught the strategies, and most strategies did not require students to think deeply about the material they were learning (Ray et al. 2015). The teachers in the study were committed to using a variety of writing strategies to push student thinking; a primary reason for continuing their use of writing was the benefits they saw related to their students' disciplinary understanding. As students grew and learned through frequent writing, teachers' decisions to include writing were less challenging - they knew they were going to include it and just made it work.

\subsection{Pedagogical Benefits of Frequent Writing That Guided Teacher Decision Making}

Our teachers engaged in daily documentation of their practice and reflection on their writing practice - weekly, monthly, and looking more broadly over the quarter. This approach allowed for both reflection-in-action and reflection-on-action (Schon, 1983). After reflecting for one quarter, our teachers planned to not only sustain their writing integration, but to continue pushing themselves to critique what they were doing and why. This finding suggests that an implicit pedagogical benefit was teachers' decision-making process was eased as teachers integrated more writing. Their thought processes became less about "will I fit writing into this lesson?" and more about "how will I integrate writing into this lesson?" If we provide teachers with the time and space to experiment with research-based writing practices strategically and thoughtfully and reflect on this process, the pedagogical benefits they experience can lead to implementation of best practices. According to our teachers, reflective practice related to frequent writing merited pedagogical benefits including renewing their commitment to regular writing, promoting a critical approach to instructional decision making (Ghanizadeh \& Moafian, 2011), and benefiting their pedagogical content knowledge (Shulman, 1986). While the purpose of this study did not include using teachers' reflections to document their learning, we argue that our data evidenced the influence of reflection-in-action (Schon, 1983) and supports the notion that teacher practice can be viewed as moment-by-moment learning. Having students engage in consistent writing led teachers to a clearer understanding of their students' learning processes and a more focused and thoughtful approach to planning.

\section{Better Understanding of Student Learning Processes}

A pedagogical benefit teachers experienced from frequent writing was feeling that they better understood their students. This alludes to what Hattie (2009) describes 
as "visible learning" (p. 22). In other words, teachers saw writing as making their students' learning more visible to them and making their teaching more visible to students (Biggs \& Tang, 2011). Hand and Prain (2002) found that teachers tended to perceive the primary purpose of writing to be assessing students' knowledge after learning. However, after trying out a range of writing types and purposes, teachers noticed student writing could reveal students' emerging understandings as well. Through formative assessment in written form, as well as writing for other purposes, our teachers were able to better determine what their students knew, how they were learning, and where gaps needed filling. While Troia and Maddox (2004) found variation in student abilities and the challenge of meeting many students' needs as barriers to writing integration, our teachers viewed writing itself as a way to mediate challenges with differentiation. For Craig, this was true as he explored the most useful feedback to give individual students, and for Jennifer, this was true as used writing techniques to scaffold for differing student needs. Teachers knew their students better and were able to push students' thinking further through the use of writing. Like the teachers in Hand and Prain's (2002) study, who felt student writing gave them an accurate picture of student thinking, writing offered our teachers a closer look at when students had misconceptions that needed to be addressed. Teachers were continually looking at ways to understand their students' learning processes in more nuanced ways, and this informed their decision making around planning lessons.

\section{Planning More Attentively}

While analyzing teacher strategy use was beyond the scope of this study, our teachers attributed pedagogical benefits to frequent writing use, one of which was more attentive planning. The teachers explored specific ways to link writing to the tasks in their discipline (Brozo \& Crain, 2017), which suggests they were thoughtful in their choice and teaching of writing strategies. Similar findings from Carter and colleagues (2016) in a study looking at professional learning related to academic language instruction, showed that teachers viewed reflection as first bringing heightened awareness to their practice, which was then a primary contributor to their planning. Each of the four teachers mentioned that they were looking to improve their practice, in relation to writing and overall. When it came to what was working for their students, what was not, and how they could use this in their planning, the teachers consistently evaluated themselves in a variety of ways.

The teachers' evaluative stance was evidence of their openness to better plan to meet the needs of their students. For Ashley, this meant identifying precise points in her lessons to embed writing where she thought students would experience the most impact, as related to her disciplinary objective. For Brittany, this meant getting outside of her comfort zone and integrating writing in new and different ways. Just the commitment to maintaining daily writing also helped the teachers work toward 
purposeful integration of writing into their lessons. Part of their evaluative stance involved recognizing the types of writing and writing instruction that they were and were not using, and this ultimately expanded their repertoire for writing in their content areas. Finally, daily writing influenced teachers' planning by helping them be more mindful of offering authentic writing experiences and aligning writing more closely with their disciplinary goals.

\section{Future Research}

Educators and researchers agree that writing in secondary classrooms is important for students, yet years of research indicates the amount and depth of writing continues to be dismal. Our study looked at the instructional decision making of teachers who are committed to frequent writing integration. Findings suggest that committing to frequent writing integration can (1) enhance students' writing and disciplinary knowledge, and (2) enrich teacher knowledge related to supporting students' writing practices and using writing as a tool for learning in the content areas. While these findings provide meaningful insights on why teachers choose to integrate writing frequently, we were also left with several questions for future research. To ensure that secondary students are supported with writing in ways that will ensure disciplinary learning and ensure college and career readiness, continued research on writing and writing instruction in secondary classrooms is vital.

First, how do teachers define learning and writing in their content areas? It appeared that each teacher in this study had slightly different notions of learning - some of which focused on content, some on developing habits of mind, some on engaging in disciplinary practices, and some on test preparation (e.g., AP History). The benefits of frequent writing that teachers described were often attached to their contexts, implying they viewed writing and learning through the lens of being a participant in their unique environment. According to Borko (2004), the contexts in which teachers are situated influence what and how they learn, as well as how their conceptions of learning inform their practice. We also wonder about teachers' perceptions of their work in relation to other disciplinary experts in their field. Lillge (2012) cited the disconnect between content area teachers and disciplinary experts as a roadblock to writing integration. This was reinforced by our finding that little of the teachers' instructional decision-making involved discipline-specific ways of writing like experts. Teachers' perceived positioning can contribute to the way they view learning and writing, as well as their priorities when teaching. Like Munby (1989), we reject the idea that Schon's reflection-in-action is the sole source of professional knowledge and growth. So, in addition to teacher experiences, what characteristics contribute to their uptake or rejection of frequent writing?

A related consideration is the correlation between specific teacher and student outcomes and increased writing frequency. Wright and colleagues (2019) found that 
students with low writing motivation and disciplinary knowledge had the most significant gains from their writing intervention. Thus, a quantitative look at motivation and achievement outcomes in classrooms where writing is integrated frequently, for example, may be a meaningful next step for researchers. To extend the work of Wilcox and Jeffrey (2015), who looked at English learners' stances toward writing in the content areas, more research on the intersection of teacher and student perspectives on writing in the content areas would offer a meaningful contribution to the current literature base. Further, researchers should consider the relationship of teachers' beliefs and instructional decision making to the success of both typically achieving and struggling writers, as well as students of various ethnic and linguistic backgrounds, across the content areas. While the teachers in our study were evaluating their purposes for writing, we wonder how their students viewed these purposes, and if and how these views may have contributed to their writing and learning.

Next, how might we shift the writing paradigm in teacher education programs and professional learning initiatives toward a stronger commitment to frequent use of writing? Approaching writing from a value-added perspective, as opposed to approaching writing as a policy requirement, could have powerful implications. Additionally, while teachers need to know the effective components (Klein \& Boscolo, 2016) of writing in the content areas, real shifts in practice can occur if teachers experience writing as a support for both the disciplinary learning and independent writing habits necessary for college and career readiness. When our teachers saw the benefits of writing over time, their buy-in deepened. We suggest that writing practice is impacted by teacher beliefs about writing, but practice can also impact perceptions and beliefs. The power of direct experience to shape teacher beliefs and practice is documented in research using teacher reflection (Tillema, 2000) and experiential learning (Kolb, 1984). Teacher education programs for secondary teacher candidates often include one literacy course in which writing instruction is embedded. This may be leading to what Troia et al. (2011) found as teachers having a narrow view of writing instruction. Portraying the importance of writing in a way that highlights student benefits, in transparent and disciplinespecific ways, has the potential to encourage teachers in all content areas to regularly integrate writing. The research reported here relied on surveys, interviews, and reflections. Future research might consider collecting additional forms of data, such as focus groups that would allow for teachers to engage in dialogue about why they do or do not integrate writing frequently and how they might improve their writing practice to better serve students.

\section{Conclusions}

Despite the benefits of writing and perhaps in light of the increased pressures regarding writing in U.S. schools, the juxtaposition of challenge and reward present 
in Jennifer's opening quote was not void throughout our teachers' reflections. Our data analysis prioritized exploring the reasons teachers described for integrating frequent writing. The drive to consider the instructional decision making of these particular teachers was rooted in our noticing that something was different about them - they did not all claim to enjoy teaching writing or writing themselves. Similarly, each of our teachers was not particularly confident in all aspects of teaching writing. However, our data implied that the benefits teachers experienced and saw their students experiencing overshadowed the challenges. While integrating writing into each content area has been recognized as challenging for student writers (Troia \& Graham, 2003) and for teachers (O'Brien, Stewart, \& Moje, 1995; Warren-King \& Warren, 2013), the teachers in our study were committed. Our teachers informed their pedagogy by setting goals and reflecting on their practice and goals regularly. Using writing more often led to teachers striving to try even more writing in their courses, which appeared to drive progressively more student writing throughout the term.

While previous research notes that teacher beliefs about writing can (Moje, 2015; Troia et al., 2011) but sometimes do not (Li \& Walsh, 2011; Phipps \& Borg, 2009) impact their practice, our study shows that this relationship is more complex. Our findings highlight the iterative nature of beliefs and practice, within specific contexts and disciplines, evidencing a bi-directional relationship. In other words, teachers' beliefs impacted their practice, but their practice also impacted their beliefs. Reflecting on instructional decision making around writing showed that the benefits teachers were experiencing from frequent writing were more impactful to their decision-making processes than their beliefs or attitude toward writing.

Similarly, we argue that contextualized teacher inquiry (Fichtman \& YendolSilva, 2003) can crystalize teachers' understanding of student learning in ways that are not afforded by traditional professional learning alone. When actually experiencing the benefits of writing, the value of writing was no longer abstract to our teachers. Having this concrete experience provided meaningful and immediately usable information to push their student-centered approaches to instruction forward. Thus, teachers who engage in frequent writing can be positioned to serve as literacy leaders in their schools and districts to share with other teachers the gains that writing can yield. While meaningful initiatives such as the National Writing Project (NWP; Whitney \& Sarraga-Lopez, 2019) are useful for teachers, not all teachers are willing or able to engage in such initiatives. Additionally, those teachers who are already committed to and skilled with writing are oftentimes those that seek out targeted writing professional learning experiences. However, we argue that all teachers can study their own practice, in ways such as those presented in this study. This focus on exploring decision making does not require a long-term commitment from teachers that may extend beyond their school, their workload, or their already extensive responsibilities. 
Our findings offer a unique perspective on teachers' decision making and buyin as related to writing - the perspective of teachers who are committed to and engaging in frequent writing integration. This perspective offers implications for school leaders, teacher educators, and teachers. First, school leaders and teacher educators should view our results as an indication that despite any negative beliefs or personal feelings toward writing that teachers may enter the field with, their practice can still include meaningful writing routines. Second, when teachers are invested in writing instruction because they have seen the benefits to their students and to their teaching, it is more likely that their writing practice will be sustained. Similarly, teacher candidates should be exposed to writing instruction in ways that do not simply prioritize adherence to district expectations and policy mandates. Further, if both teacher preparation programs and districts expect teachers to be invested in writing instruction, their programs and initiatives should show an enhanced commitment to supporting teachers with writing instruction. In sum, when integrating writing frequently, teachers see distinct pedagogical benefits, and more importantly, student benefits that impact their instructional decision making related to writing. This relationship should be considered as we continue to explore ways to ensure students leave secondary schools prepared for postsecondary success.

\section{References}

Anderson, P., Anson, C., Fish, T., Gonyeat, R., Marshall, M., Menefee-Libey, W., Paine, C. Palucki, L. Weave, S. (2017). How writing contributes to learning: new findings from a national study and their local application. New Frontiers, 19(1).

Applebee, A. N., \& Langer, J. A. (2009). What is happening in the teaching of writing? English Journal, 98(5), 18-28.

Applebee, A. N., \& Langer, J. A (2011). A snapshot of writing instruction in middle schools and high schools. English Journal, 100(6), 14-27.

Applebee, A. N., \& Langer, J. A. (2013). Writing instruction that works: Proven methods for middle and high school students. New York, NY: Teachers College Press and National Writing Project.

Carter, H., Crowley, K., Townsend, D., \& Barone, D. (2016). Secondary teachers and academic language instruction across contents: Reflections from a year of professional learning. Journal of Adolescent and Adult Literacy, 60(3), 325-334. http://dx.doi.org/10.1002/jaal.554

Bangert-Drowns, R. L., Hurley, M. M., \& Wilkinson, B. (2004). The effects of school-based Writing-to-Learn interventions on academic achievement: A meta-analysis. Review of Educational Research, 74, 29-58. http://dx.doi.org/10.3102/00346543074001029

Beach, S. A. (1994). Teacher's theories and classroom practice: Beliefs, knowledge, or context? Reading Psychology, 15(3), 189-196. https://doi.org/10.1080/0270271940150304

Bean, T. W. (2000). Reading in the content areas: Social constructivist dimensions. In M. L. Kamil, P. B. Mosenthal, P. D. Pearson, \& R. Barr (Eds.), Handbook of Reading Research (pp. 629-644). Mahwah, NJ: Lawrence Erlbaum Associates.

Berry, R. A. W. (2006). Creating a better classroom environment for students with learning disabilities. Learning Disability Quarterly, 32(3), 123-141.

Biggs, J. \& Tang, C. (2011). Teaching for quality learning at university (4 ${ }^{\text {th }}$ ed.). New York, NY: The Society for Research into Higher Education \& Open University Press. 
361 | JOURNAL OF WRITING RESEARCH

Boscolo, P., \& Mason, L. (2001). Writing to learn, writing to transfer. In Writing as a learning tool (pp. 83-104). Springer, Dordrecht.

Borko, H. (2004). Professional development and teacher learning: Mapping the terrain. Educational Researcher, 33(8), 3-15. http://dx.doi.org/10.3102/0013189X033008003

Braun, V. \& Clarke, V. (2006) Using thematic analysis in psychology. Qualitative Research in Psychology, 3(2), 77-101. http://dx.doi.org/10.1191/1478088706qp063oa

Braun, V., \& Clarke, V. (2012). Thematic analysis. In H. Cooper, P. M. Camic, D. L. Long, A. T. Panter, D. Rindskopf, \& K. J. Sher (Eds.), APA handbooks in psychology ${ }^{\circledR}$. APA handbook of research methods in psychology, Vol. 2. Research designs: Quantitative, qualitative, neuropsychological, and biological (p. 57-71). American Psychological Association. https://doi.org/10.1037/13620-004

Brozo, W. \& Crain, S. (2017). Writing in math: A disciplinary literacy approach. The Clearing House: A Journal of Educational Strategies, Issues, and Ideas. 91(7), 1-7. http://dx.doi.org/10.1080/00098655.2017.1342435

Cantrell, Susan \& Callaway, Patricia. (2008). High and low implementers of content literacy instruction: Portraits of teacher efficacy. Teaching and Teacher Education. 24(7). 1739-1750. http://dx.doi.org/10.1016/j.tate.2008.02.020.

Collin, R. (2014). A Bernsteinian analysis of content area literacy. Journal of Literacy Research, 46(3), 306-329. http://dx.doi.org/10.1177/1086296X14552178

Corcelles, M., \& Castelló, M. (2017). Learning philosophical thinking through collaborative writing in secondary education. Journal of Writing Research, 2015, 7(1), 157-200. https://doi.org/10.17239/jowr-2015.07.01.07

Daisey, P. (2009). The writing experiences and beliefs of secondary teacher candidates. Teacher Education Quarterly, 36(4), 157-172.

Drew, S. V., Olinghouse, N. G., Faggella-Luby, M., \& Welsh, M. E. (2017). Framework for disciplinary writing in science grades 6-12: A national survey. Journal of Educational Psychology, 109, 935-955. http://dx.doi.org/10.1037/edu0000186

Fisher, D. \& Ivey, G. (2005). Literacy and language as learning in content-area classes: A departure from "Every Teacher a Teacher of Reading". Action in Teacher Education. 27(2), 3-11. http://dx.doi.org/10.1080/01626620.2005.10463378

Fichtman, N. D. \& Yendol-Silva, D. (2003). The reflective educator's guide to classroom research. Thousand Oaks, CA: Corwin.

Gabriel, R., \& Dostal, H. (2015). Interactive writing in the disciplines: A common core approach to disciplinary writing in middle and high school. Clearing House, 88(2), 66-71. http://dx.doi.org/10.1080/00098655.2015.1005036

Ghanizadeh, A., \& Moafian, F. (2011). The relationship between Iranian EFL teachers' sense of self-efficacy and their pedagogical success in Language Institutes. Asian EFL Journal, 13 (2), 249-272.

Gilbert, J. \& Graham, S. (2010). Teaching writing to elementary students in grades 4-6: A national survey. The Elementary School Journal, 110(4), 494-518. http://dx.doi.org/10.1086/651193

Gillespie, A., Graham, S., Kiuhara, S., \& Hebert, M. (2014). High school teachers' use of writing to support students' learning: A national survey. Reading and Writing: An Interdisciplinary Journal, 276), 1043-1072. http://dx.doi.org/10.1007/s11145-013-9494-8

Graham, S. (2018). A revised writer (s)-within-community model of writing. Educational Psychologist, 53(4), 258-279. http://dx.doi.org/10.1080/00461520.2018.1481406

Graham, S. (2019). Changing how writing is taught. Review of Research in Education, 43(1), $277-$ 303. http://dx.doi.org/10.3102/0091732X18821125

Graham, S., Capizzi, A., Harris, K. R., Hebert, M., \& Morphy, P. (2014). Teaching writing to middle school students: A national survey. Reading and Writing, 276), 1015-1042. http://dx.doi.org/10.1007/s11145-013-9495-7 
Graham, S., Harris, K. R., \& Chambers, A. B. (2016). Evidence-based practice and writing instruction: A review of reviews. In C. A. MacArthur, S. Graham, \& J. Fitzgerald (Eds.), The handbook of writing research (2nd ed., pp. 211-226). New York, NY: Guilford Press.

Graham, S., Harris, K. R., \& Santangelo, T. (2015). Research-based writing practices and the common core: Meta-analysis and meta-synthesis. The Elementary School Journal, 115(4), 498-522. http://dx.doi.org/10.1086/681964

Graham, S., \& Hebert, M. (2010). Writing to read: Evidence for how writing can improve reading. A report from the Carnegie Corporation of New York.

Graham, S., Kiuhara, S. A., \& MacKay, M. (2020). The effects of writing on learning in science, social studies, and mathematics: A meta-analysis. Review of Educational Research, 90(2), 179-226. http://dx.doi.org/10.3102/0034654320914744

Graham, S., McKeown, D., Kiuhara, S., \& Harris, K. R. (2012). A meta-analysis of writing instruction for students in the elementary grades. Journal of educational psychology, 104(4), 879. http://dx.doi.org/10.1037/a0029185

Graham, S., \& Perin, D. (2007). A meta-analysis of writing instruction for adolescent students. Journal of Educational Psychology, 99(3), 445-476. http://dx.doi.org/10.1037/00220663.99.3.445

Hand, B., \& Prain, V. (2002). Teachers implementing writing-to-learn strategies in junior secondary science: A case study. Science Education, 86(6), 737-755. https://doi.org/10.1002/sce.10016

Hattie, J. (2009) Visible learning: A synthesis of $800+$ meta-analyses on achievement. London: Routledge.

International Literacy Association (ILA). (2017). Content area and disciplinary literacy: Strategies and frameworks [Literacy leadership brief]. Newark, DE: Author.

Jenkins, K.D. (2018). Understanding Teacher beliefs and instructional decision making concerning disciplinary literacy: The case of secondary teachers in an urban school. International Journal of Learning, Teaching and Educational Research, 1711), 175-196. http://dx.doi.org/10.26803/ijlter.17.1.11

Klein, P.D., Boscolo, P. (2016). Trends in research on writing as a learning activity. Journal of Writing Research, 73), 311- 350. http://dx.doi.org/10.17239/jowr-2016.07.03.01

Klein, P. D., \& Kirkpatrick, L. C. (2010). A framework for content area writing: Mediators and moderators. Journal of Writing Research, 2(1). http://dx.doi.org/10.17239/jowr-2010.02.01.1

Kiuhara, S., Graham, S., \& Hawken, L. (2009). Teaching writing to high school students: A national survey. Journal of Educational Psychology, 101(1), 136160. http://dx.doi.org/10.1037/a0013097

Kolb, D.A. (1984). Experiential learning: Experience as a source of learning and development. Englewood Cliffs, NY: Prentice-Hall.

Lawrence, J. F., Galloway, E. P., Yim, S. B., \& Lin, A. (2013). Learning to write in middle school: Insights into adolescent writers' instructional experiences across content areas. Journal of Adolescent and Adult Literacy, 58(30), 243-254. http://dx.doi.org/10.1002/JAAL.219

Li, L., \& Walsh, S. (2011). 'Seeing Is Believing': looking at EFL teachers' beliefs through classroom interaction. Classroom Discourse, 2, 39-57. http://dx.doi.org/10.1080/19463014.2011.562657

Lillge, D. (2012). Illuminating possibilities: Secondary writing across the curriculum as a resource for navigating common core state standards. Across the Disciplines, $9(3)$. http://dx.doi.org/10.37514/ATD-J.2012.9.3.09

Luna, M., Villalón, R., Mateos, M., \& Martín, E. (2020). Improving university argumentative writing through online training. Journal of Writing Research, 12(1), 233-262. 10.17239/jowr2020.12.01.08

Manchón, R. M. (2011). Situating the learning-to-write and writing-to-learn dimensions of L2 writing. In R. M. Manchón (Ed.), Learning-to-write and writing-to-learn in an additional language (pp. 3-14). Amsterdam: John Benjamins. 
McCarthey, S. J., \& Mkhize, D. (2013). Teachers' orientations towards writing. Journal of Writing Research, 5(1), 1-33. http://dx.doi.org/ 10.17239/jowr-2013.05.01.1

Merriam, S. B. (2009). Qualitative research: A guide to design and implementation (3rd ed.). San Francisco, CA: Wiley.

Meizlish, D., LaVaque-Manty, D., Silver, N., \& Kaplan, M. (2013). Think like/write like: Metacognitive strategies to foster students' development as disciplinary thinkers and writers. In Thompson, R. J. (Ed.), Changing the conversation about higher education (pp. 53-73). Lanham, MD: R\&L Education.

Miles, M.B. \& Huberman, A.M. (1994). Qualitative data analysis: An expanded sourcebook. London: Sage.

Munby, H. (1989). Reflection-in-action and reflection-on-action. Education and Culture, 9(1), 31-42. Retrieved from https://docs.lib.purdue.edu/eandc/vol09/iss1/art4

Monte-Sano, C. \& De La Paz, S. (2012). Using writing tasks to elicit adolescents' historical reasoning. Journal of Literacy Research, 44(3), 273-299. http://dx.doi.org/10.1177/1086296X12450445

Moje, E. B. (2015). Doing and teaching disciplinary literacy with adolescent learners: A social and cultural enterprise. Harvard Educational Review, 85(2), 254-278. http://dx.doi.org/10.17763/0017-8055.85.2.254

National Commission on Writing. (2003). The neglected " $R$ ": The need for a writing revolution. Washington, DC: College Board. Retrieved from http://www.collegeboard. com/prod_downloads/writingcom/neglectedr.pdf

National Council for Teachers of English. (2011). Reading and writing across the curriculum. A policy research brief produced by the National Council for Teachers of English. Urbana, IL: James R. Squire Office of Policy Research. Retrieved from http://www.ncte.org/library/NCTEFiles/Resources/Journals/CC/0203mar2011/CC0203Policy.pdf

National Governors Association Center for Best Practices \& Council of Chief State School Officers. (2010). Common Core State Standards for English language arts and literacy in history/social studies, science, and technical subjects. Washington, DC: Authors.

Narváez-Cardona, Elizabeth. (2016). Latin-American writing initiatives in engineering from Spanish-speaking countries. I/ha do Desterro, 69(3), 223-248. https://dx.doi.org/10.5007/2175-8026.2016v69n3p223

Neely, M. E. (2014). Epistemological and writing beliefs in a first-year college writing course: Exploring shifts across a semester and relationships with argument quality. Journal of Writing Research, 6(2), 141-147. http://dx.doi.org/10.17239/jowr-2014.06.02.3

O'Brien, D. G., Stewart, R. A., \& Moje, E. B. (1995). Why content literacy is difficult to infuse into the secondary school: Complexities of curriculum, pedagogy, and school culture. Reading Research Quarterly, 30(3), 442-463. http://dx.doi.org/10.2307/747625

Palinkas, L. A., Horwitz, S. M., Green, C. A., Wisdom, J. P., Duan, N., \& Hoagwood, K. (2015). Purposeful sampling for qualitative data collection and analysis in mixed method implementation research. Administration and Policy in Mental Health, 42(5), 533544. http://dx.doi.org/10.1007/s10488-013-0528-y

Phipps, S. \& Borg, S. (2009). Exploring tensions between teachers' grammar teaching beliefs and practices. System. 37(3), 380-390. http://dx.doi.org/10.1016/j.system.2009.03.002

Powell, S. R., Hebert, M. A., Cohen, J. A., Casa, T. M., \& Firmender, J. M. (2017). A synthesis of mathematics writing: Assessments, interventions, and surveys. Journal of Writing Research, 8(3). doi: 10.17239/jowr-2017.08.03.04

Quitadamo, I. J., \& Kurtz, M. J. (2007). Learning to improve: Using writing to increase critical thinking performance in general education biology. CBE-Life Sciences Education, 6(2), 140-154. http://dx.doi.org/10.1187/cbe.06-11-0203 
Quitadamo I. J., Faiola C. L., Johnson J. E., Kurtz M. J. (2008). Community-based inquiry improves critical thinking in general education biology. CBE-Life Sciences Education, (3), 327-337. https://doi.org/10.1187/cbe.07-11-0097.

Ray, A. \& Graham, S. \& Houston, J. \& Harris, K. (2016). Teachers' use of writing to support students' learning in middle school: A national survey in the United States. Reading and Writing. 29(5), 1039-1068. http://dx.doi.org/10.1007/s11145-015-9602-z

Rivard, L. P. (1994). A review of writing to learn in science: Implications for practice and research. Journal of Research in Science Teaching, 31, 969-983. http://dx.doi.org/10.1002/tea.3660310910

Reynolds, J. A., Thaiss, C., Katkin, W., \& Thompson, R. J. (2012). Writing-to-learn in undergraduate science education: A community-based, conceptually driven approach. CBE-Life Sciences Education, 11(1), 17-25. https://doi.org/10.1187/cbe.11-08-0064

Saldana, J. (2016). The coding manual for qualitative researchers (3rd ed.). London: Sage.

Sampson, V., Enderle, P., Grooms, J., \& Witte, S. (2013). Writing to learn by learning to write during the school science laboratory: Helping middle and high school students develop argumentative writing skills as they learn core ideas. Science Education, 97(5), 643-670. http://dx.doi.org/10.1002/sce.21069

Schön, D. A. (1983). The reflective practitioner: How professionals think in action. New York: Basic Books.

Shanahan, T. \& Shanahan, C. (2008). Teaching disciplinary literacy to adolescents: Rethinking content area literacy. Harvard Educational Review. 78. http://dx.doi.org//10.17763/haer.78.1.v62444321p602101

Shulman, L. S. (1986). Those who understand, knowledge growth in teaching. Educational Researcher, 15(2), 4-14. http://dx.doi.org/10.3102/0013189X015002004

Shavelson, R. J., Webb, N. M., \& Burstein, L. (1986). Measurement of teaching. Handbook of research on teaching, 3(1), 50-91.

Stake, R. E. (1995). Case studies. In N. K. Denzin \& Y. S. Lincoln (Eds.). Handbook of Qualitative Research (pp. 236-247). Thousand Oaks, Sage Publications.

Tillema, H.H. (2000). Belief change towards self-directed learning in student teachers: Immersion in practice or reflection on action. Teaching and Teacher Education 16, 575591.http://dx.doi.org/10.1016/S0742-051X(00)00016-0

Thaiss, C., \& Porter, T. (2010). The state of WAC/WID in 2010: Methods and results of the U.S. survey of the international WAC/WID mapping project. College Composition and Communication, 61(3), 534-570.

Thaiss, C. (2012). Origins, aims, and uses of writing programs worldwide: Profiles of academic writing in many places. Writing Programs Worldwide: Profiles of Academic Writing in Many Places. Fort Collins, CO: The WAC Clearinghouse.

Townsend, D., Taboada Barber, A, Carter, H., \& Salas, R. (2020). More than words: Older adolescents' linguistic resources in the context of disciplinary achievement and academic risk. Reading Psychology, 41(8), 778-802, DOI: 10.1080/02702711.2020.1782291

Troia, G., \& Graham, S. (2003). Effective writing instruction across the grades: What every educational consultant should know. Journal of Educational and Psychological Consultation, 14(1), 75-89. https://doi.org/10.1207/S1532768XJEPC1401_04

Troia, G. \& Lin, S., \& Cohen, S. \& Monroe, B. (2011). A Year in the writing workshop: Linking writing instruction practices and teachers' epistemologies and beliefs about writing instruction. The Elementary School Journal, 112(1), 155-182. http://doi.org/10.1086/660688

Troia, G. A., \& Maddox, M. E. (2004). Writing instruction in middle schools: Special and general education teachers share their views and voice their concerns. Exceptionality, 12(1), 19-37. http://dx.doi.org/10.1207/s15327035ex1201_3

Tschannen-Moran, M., Woolfolk Hoy, A., \& Hoy, W. K. (1998). Teacher efficacy: Its meaning and measure. Review of Educational Research, 68(2), 202-248. 
365 | JOURNAL OF WRITING RESEARCH

https://doi.org/10.2307/1170754

U.S. Department of Education Institute of Education Sciences. (2017). X County School District. Washington, DC: National Center for Educational Statistics.

Van Drie, J., Braaksma, M., \& van Boxtel, C. (2015). Writing in History: Effects of writing instruction on historical reasoning and text quality. Journal of Writing Research, 7(1), 123156. http://dx.doi.org/10.17239/jowr-2015.07.01.06

Warren-King, B. Z., \& Warren, G. A. (2013). Changing the attitudes of pre-service teachers toward content literacy strategies. Reading Improvement, 50(2), 75-82.

Wallace, C. S., Hand, B. B. \& Prain, V. (2004). Writing and learning in the science classroom. The Netherlands: Kluwer.

Whitney, A. E. \& Sarraga-Lopez, Y. (2019). The history of the National Writing Project. New York, NY: Oxford.

Wilcox, K. \& Jeffery, J (2015). Adolescent English learners' stances toward disciplinary writing. English for Specific Purposes, 38, 44-56. http://dx.doi.org/10.1016/j.esp.2014.11.006

Wright, K. L., Hodges, T. S., \& McTigue, E. M. (2019). A validation program for the Self-Beliefs, Writing-Beliefs, and Attitude Survey: A measure of adolescents' motivation toward writing. Assessing Writing, 39, 64-78. http://dx.doi.org/10.1016/j.asw.2018.12.004

Wyse, D., \& Ferrari, A. (2015). Creativity and education: Comparing the national curricula of the states of the European Union and the United Kingdom. British Educational Research Journal, 41(1), 30-47. http://dx.doi.org/10.1002/berj.3135

Yang, H (2015). Teacher mediated agency in educational reform in China. Switzerland: Springer.

Yin, R. K. (2014). Case study research: design and methods ( $6^{\text {th }}$ ed.). Thousand Oaks, CA: Sage. 